\section{New Beginnings within a Library Career}

\section{Elizabeth Leonard}

Correspondence concerning this column should be addressed to: Elizabeth Leonard, Assistant Dean of Information Technologies and Collection Services at Seton Hall University; email: RUSQCareerConvo@gmail.com.
Welcome to our new RUSQ column, Career Conversations. This regular column will explore career issues that librarians are facing, what the research says, and how you and your peers are managing these challenges. Have a topic you'd like to explore? Email us at RUSQCareerConvo@gmail .com.-RUSQ Editor

\section{WHY AM I TALKING WITH YOU?}

Like an interview, I'll start this column with a version of everyone's "favorite" interview question, "Tell us about yourself." For my entire adult life, I've been interested in career counseling and human resources. I began working as a freelance résumé writer and editor during my undergraduate days. Over the years in this field, I have helped individuals in a variety of industries and personnel levels, from hourly workers to C-level executives, secure interviews and obtain positions. During the early 2000s, I spent several years as a career counselor for a Department of Defense contractor. Years later, I cofounded the "I Need a Library Job" Facebook group with Naomi House.

My career prior to librarianship was in information technology. I fell into IT when the internet was a new, foreign thing to most. I found that I was really good at technology, and I enjoyed the innovation and problem solving that went hand in hand with those early days of IT. My skills led to work teaching others about technology, and then to system development for technology, and work for the Department of Defense. Then I took a couple of years off to stay at home with my newborn son.

As some of you know and others might surmise, three years away from the technology field meant that I was a dinosaur and unemployable. Combine that with the recession of 2008 and a major change in life circumstance, and I decided to fulfill a childhood dream and remake my life. So I became a librarian. Fast forward a couple of years, one job change, and here I am.

\section{IN THEIR WORDS-CAREER TRANSITIONS}

One of the questions I have heard many times over the years (and one I have asked myself more than once) has been how to make a major shift. There are many reasons one might want a change: a geographic move resulting in less options in your chosen area, a desire to explore new options, an 


\section{CAREER CONVERSATIONS}

emerging passion for a different field, or perhaps a lack of interest or advancement options in your existing role. I spoke with a number of self-identified librarians who have changed from one type of librarianship to another to find out how they did it.

Hailey McCollough, Department Head of Adult Services at a public library, left her position as a college librarian (sole librarian in charge) one year ago. She was glad the public library took a chance on her. "After I got the position, [my boss] told me I interviewed really well and had good answers for all the questions. ... Because I had experience running my own library, I was a good fit for the department head/ management position they were looking to fill." In McCollough's case, she had several specialized skills that helped her succeed in her new job, including collection weeding, as well as management of student workers at the college library and supervisor experience in retail and customer service jobs she had had prior to obtaining her library science degree. Finally, she felt her personality was a good match to their needs. After she obtained the position, McCollough proved her worth by taking on extra work that would help her learn more in areas that she felt she had little experience in. Her initiative made a positive impact on her supervisors.

Kathy Marquis had a twenty-five-year career in archival reference when she moved to Wyoming fifteen years ago. She applied for an opening in her area for an adult services librarian at a public library. In those days, an MLIS was not required for all positions simply because there were not enough candidates who had the degree, so her MLIS was enough to attract the attention of the hiring committee. She supported her application with transferable reference skills, and impressed the committee with an interest in the position, as well as a demonstrated desire to learn about collection development and programming. Finally, she strategically asked her references to focus on the "public library-like experience" at her previous position, a large state historical society. After she started at the public library, she showed her value by applying for and obtaining grants, a skill which she taught herself.

Another librarian working in a research university archives who moved to an academic position noted that she emphasized the transferable skills she had, rather than her technical skill set. She said, "It's all about spinning what looks like your lack of experience in the pivot field as helpful context that sets you apart." She told me that her experiences with primary sources and research instruction, as well as one-on-one research assistance, were helpful in obtaining the position. While the context wasn't the same, the skills were.

Sarah Cornell, Supervisor of Technical Services at the Portsmouth Public Library, balanced her interests between early master's level coursework in public librarianship and a job as an academic librarian paraprofessional while in library school. She assumed she'd work as a public librarian, but instead, went to Rome and worked in a special library. When she returned to the United States, she reassessed her goals.
She ended up obtaining a job as a librarian in a small college by marketing her diverse background in special libraries combined with her public library coursework. While an academic librarian, she obtained experience designing processes, and when she later moved to public librarianship, those programs gave her an edge-it hadn't mattered to the public library director that those skills were transferred from the special library realm.

Cathy Mayer, Director of the Library at Trinity Christian College, was a high school librarian before she moved to the directorship. When she hit an institutional ceiling, she knew she needed a change. She saw the advertisement for the position she currently holds but initially didn't apply because it was outside of her industry, and she didn't think she had a real chance. After friends encouraged her, she reviewed the essential core skills of the position, reflected on how she could speak to those needs, and then reformatted her résumé in a functional style so she could leverage those skills. Even so, the hiring committee was initially very skeptical of her candidacy. She won them over through her understanding of systems, professionalism, and energy, something that was seen as lacking in the library at that time. After she was hired, faculty came to value that she really understood what first-year students had experienced in high school and what they could or should be expected to know. Finally, after she was hired, she augmented her skills by attending the ACRL College Library Mentor Director program.

The biggest difference between academic and public librarianship, said Theresa Cahill Agostinelli, was the time spent helping students with citations. Agostinelli, who works as an academic reference librarian in New Jersey, worked as a graduate assistant in a university library during her MLS studies and then moved to public libraries for twenty years. She made a decision to be an active leader in organizations that served both academic and public librarians. During her tenure as a public librarian, she developed a strong set of technology skills, including web publishing, as well as creating screencasts and handouts. Finally, she was able to present herself as someone who embraced the cutting edge both in her past work as well as her service work. This, along with her passion and attention to the presentation made during the academic interview process, made an impact on the hiring committee.

\section{TAKEAWAYS FOR YOUR OWN CHANGE}

Don't fear the risk. If you have a job, then you risk nothing by trying to get another. If you have no current position, you lose nothing by trying. Not getting the job doesn't mean you are less of a person; it means you are more because you made the attempt.

Try for the position. Even though you might not think you are a perfect match for the position, it doesn't mean you aren't the best candidate for the job. I hope that this advice will be taken seriously, especially by women reading this 
column. In the twenty-five years I've been hiring librarians, staff, and other personnel, I have never found any candidate that filled the job description exactly, but men are more likely to apply anyway.

There are certain types of skills that are always transferrable: for example, several librarians with whom I spoke mentioned that project management, program development, acquisitions, budgeting, instruction skills, and supervisory skills tend to transfer very well. Then there are ones that can be transferable if you think about them in the right way. Working in an urban public library can help you obtain a position at a higher education institution that specializes in first generation college students. Cathy Mayer was able to win over skeptical faculty by presenting her background as relevant and transferable.

What if you really don't have the experience but want a position in a new field? Try finding volunteer work to build experience, as Theresa Cahill Agostinelli did. Homol suggests learning more by reading the industry literature, joining the field's main listservs, and taking webinars. ${ }^{1}$ Altman suggested looking for MOOCs (massive open online courses) to augment your skills, as lifelong learners are attractive job candidates. $^{2}$

What is as important as the qualifications on paper is the personal narrative. The common thread through the women I interviewed for this column was the way they were able to impress the hiring committee through a compelling story. That narrative should be tailored to each organization.
How are your experiences relevant to the organization? As Clark notes, you must provide a connection between your past, present, and future, and show how your skills provide unique advantages and value to your candidacy. ${ }^{3}$ A story built from a series of logical steps is more palatable to a potential employer than a sudden revelation. It is also an indication of outside-of-the-box thinking, which is often a highly sought-after quality.

Finally, presentation is everything. Most of those that I interviewed for this column mentioned that a positive attitude during the interview played a part in getting the job, despite a lack of experience. However, too much enthusiasm can be off-putting. It can be very difficult to strike a balance between enough energy and too much, especially in the unique pressure cooker that is the interview. Practice being yourself before you get there; like getting the job, it takes a surprising amount of work but is worth it in the end.

\section{References}

1. Lindley Homol, "Adaptable Applicants: Preparing to Change Your Library Path," Footnotes 43, no. 3 (February 2014), http:// www.ala.org/rt/nmrt/news/footnotes/february2014/adaptable -applicants-preparing-change-your-library-path.

2. Rachael Altman, "Thinking about Making a Career Transition? Highlight Your Transferable Skills," I Need a Library Job, August 25, 2015, http://inalj.com/?p=63276.

3. Dorie Clark, "How to Explain Your Career Transition," Harvard Business Review, April 3, 2013, https://hbr.org/2013/04/how-to -explain-your-career-tra. 